\title{
On Pa tshab Nyi ma grags's Way of Citing the Mūlamadhyamakakārikā in His Commentary
}

\author{
Dörte KAMARID
}

The present paper aims to analyse the citation of the MMK-kārikās in Pa tshab Nyi ma grags's commentary found in both its introductory section and Chapter One.

\section{Commentary literature mentioned by $\mathrm{Pa}$ tshab Nyi ma grags}

First, the question is what kind of commentaries Pa tshab Nyi ma grags had at hand when, during his stay in Kaśmīr, this commentary or study note was written down? Pa tshab Nyi ma grags introduced the following commentaries (3bL7-3bL9):

1) Buddhapālita was the first who composed [his own commentary], and commented [on the $\mathrm{MMK}$ ] in the way of [unwanted] consequence (prasariga).

2) Akutobhayā is generally known to have been written by Nāgārjuna but others say, "it is not so."

3) Against the profound [commentary] of Buddhapālita, Bhavyakīrti composed the Prajñāpradīpa in which, refuting the former's [way of] prasanga or [unwanted] consequence, he commented [on the MMK] in the autonomous way (svatantra).

4) Later, having refuted the autonomous way [of Bhavyakīrti's commentary], Candrakīrti vindicated Buddhapālita's exposition and commented [on the MMK] in the way of [unwanted] consequence (prasanga).

Interesting here is that according to Pa tshab Nyi ma grags's understanding, Buddhapālita was the first commentator of the above four and he commented in the way of unwanted consequence (prasanga). Also, the authorship of Akutobhayā was already doubted at that time.

\section{Analysis of the citation of the MMK-kārikās}

Observing the introductory section (1bL1-5aR11) and Chapter One titled Pratyayaparīksā

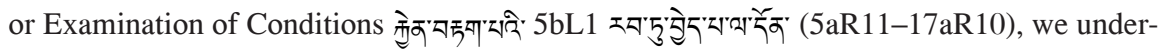
stand that out of 14 MMK-kārikās, nine verses $(2-5,7-8,11-13)$ in total are cited or par- 
tially mentioned (7-8, 11-13). Pa tshab Nyi ma grags did not quote the complete MMK$k \bar{a} r i k \bar{a}$ s. The first $k \bar{a} r i k \bar{a}$ cited by $\mathrm{Pa}$ tshab Nyi ma grags is MMK 1.3 in the introductory section (2bR2-3). Followed by the dedicatory verse composed of two ślokas where all pādas of the verse are mentioned or quoted partially, the eight negations (4bR1-5aR10) are explained in detail. The order of the Tibetan translation is not followed as such. In Chapter One, MMK 1.1 is explained (5bR8-6aL5) but not cited as a whole verse. Here, further MMK 1.3 and 1.1 will be analysed and explained in detail.

MMK 1.3

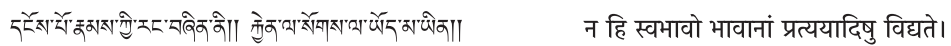

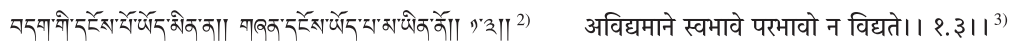

"The own-nature of things does not exist in [its] conditions and so forth. When there is no ownnature, other-nature does not exist." (MMK 1.3)

Concerning MMK 1.3, it is to be noted that Pa tshab Nyi ma grags cited the earlier render-

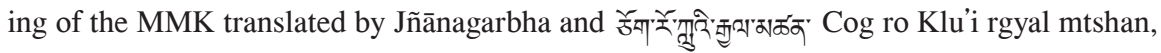
i.e., the translators of the Prajī̄a-nāma-mūlamadhyamakakārikā (1st translation), Akutobhayā (ABh), Buddhapālita-mūlamadhyamaka-vrotti (BP) and Bhāviveka's Prajñāpradīpa-mūlamadhyamaka-vrtti (PP). These were conducted in the early 9th century during the early diffusion (질 $5^{-1}$ snga dar) of Buddhism in Tibet. The translation by

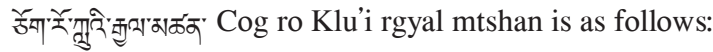

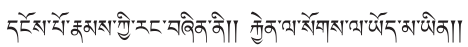

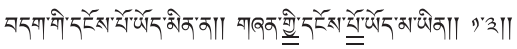

It is interesting to note that the above last $p \bar{a} d a$ is the same as that found in Pa tshab Nyi ma grags's commentary:

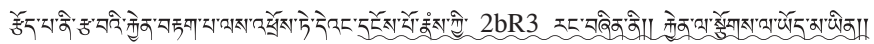

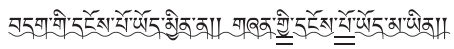

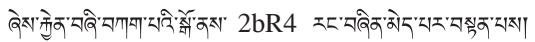

"The dispute is continued in [the first Chapter titled] "Examination of Conditions" in the Müla[madhyamakakārikā]. It elaborates that "the own-nature of things does not exist in the condition and so on. If there is no own-nature, other-nature does not exist." Because the absence of own-nature is taught by means of negating the four conditions, ...”.

In the above commentary it is clear that $\mathrm{Pa}$ tshab Nyi ma grags follows Klu'i rgyal 


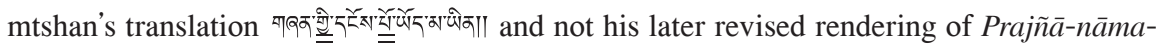
mūlamadhyamakakārikā or Prasannapadā (PsP). This shows that at the time of this manuscript, Pa tshab Nyi ma grags had probably not yet translated the PsP and instead he used the earlier translation of the MMK-kārikā by Klu'i rgyal mtshan. Pa tshab Nyi ma grags does not explicitly comment on the MMK 1.3 itself. In this introductory section, the context of citing MMK 1.3 (2bR2-3) is within the introduction to Nāgārjuna's works (2bL8). This explanation is similar to that found in the introductory section of Candrakīrti's commentary on the Yuktișaștikākārikā where MMK 1.3 is also cited. (For the different order of the MMK-kārikās 1.2 and 1.3 found between the Akutobhayā (ABh) plus Pingala's Zhōnglùn and Buddhapālita's commentary (BP), Prajñāpradīpa (PP), see Saito 2019. ${ }^{4)}$ )

MMK 1.1

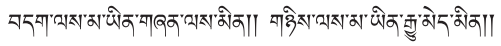

न स्वतो नापि परतो न द्वाभ्यां नाप्य् अहेतुतः।

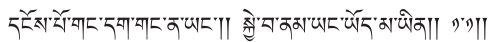

उत्पन्ना जातु विद्यन्ते भावाः क्व चन केचन।। २.१।।

"In any place, no things whatsoever ever arise, from themselves, from others, from both, or without cause." (MMK 1.1)

MMK 1.1 is not exactly cited but explained in detail. Explanations are divided in the following four sections (2.111.41-44):

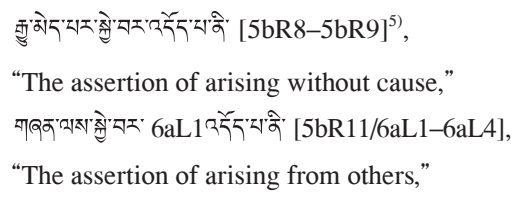
[themselves and others],"

These four categories include partial words of the kārike 1.1 . This shows that Pa tshab Nyi ma grags commented in detail on all four ways of arising systematically. Pa tshab Nyi ma grags's citation of some phrases of the MMK-kārikās 2, 4-5, 7-8 and 11-13 makes it clear that these are located nearly at the end of the First Chapter, i.e., in folios 14bR11 to 17aL10. This fact shows that giving comments on each verse of the MMK was not intended to be the main topic of Pa tshab Nyi ma grags's work as far as the First Chapter is concerned. 


\section{Various topics of studies in Kaśmīr}

Besides these several verses cited and discussed, as we saw in the above section, this commentary focuses also on presenting various argumentations of the Buddhist and Indian Philosophical thoughts. The distinction between Svātantrika and Prāsangika's ways of argumentation, in the latter of which Pa tshab Nyi ma grags takes a clear position (14aL4), is one of the most important topics dealt with in his commentary. $\left.{ }^{6}\right)$ Yoshimizu recently analysed and updated Pa tshab Nyi ma grags's understanding and emphasized that this debate was not a past debate in the sixth- and seventh-century in India, but an ongoing issue at the time of Pa tshab Nyi ma grags, being a Prāsangika translator. ${ }^{7)}$ In addition, logical issues such as of the proof of the absence of own-nature (*nihsvabhāvatā) (6aL8) and the "neither one nor many" argument (*ekāneka[virahita], 7bL11) in the form of *prasanga are discussed in detail. Pa tshab Nyi ma grags studied those topics in accordance with those Indian scholars such as Śrigupta, Śāntarakṣita and Kamalaśîla in the 8th century but defined them here in a new light of the Prāsangika. ${ }^{8)}$ It seems most probable that in order to highlight Candrakīti's approach to the Madhyamaka thought, what Pa tshab Nyi ma grags wrote in the First Chapter of his commentary shows those topics and contents of his study at Kaśmīr in late 11th century that he learned from Indian paṇditas like Mahāsumati.

\section{Conclusion}

First, Pa tshab Nyi ma grags's citation of MMK 1.3 shows clearly that, while following the previous translation by Klu'i rgyal mtshan, he had not yet translated, or at least not yet completed his translation of the Prasannapadā when he wrote this commentary. This fact may also give evidence that he had then not yet revised the earlier translation of the MMK by Klu'i rgyal mtshan. Second, in Pa tshab Nyi ma grags's detailed explanation of the dedicatory verse, he cited almost all parts of the verse and specifically commented on each of the "eight negations". This is followed by the content of MMK 1.1 that was explained but Pa tshab Nyi ma grags did not cite the verse as a whole. Third, most of the cited phrases of the MMK-kārikās (2 and 4 onwards) are located at nearly the end of the First Chapter. This shows that the explanation of the MMK-kārikās was not intended by Pa tshab Nyi ma grags to be the main topic in his commentary on the First Chapter. While presenting various topics and contents of his study in Kaśmīr, he shows the intention to emphasize his 
own position as a *Prāsangika. Further analysis as well as translation work of this important commentary is likely to be fruitful and remains the task for future research.

\section{Notes}

1) For the Introductory remarks on Pa tshab Nyi ma grags's manuscript, see Kamarid 2019.2 2) In following the Tibetan text of MMK translated by Pa tshab Nyi ma grags is cited from D no. 3824, P no. 5224. 3) Hereafter the Sanskrit text of MMK is cited from Ye 2011, 12 in which the verse in question is numbered MMK 1.2 in accordance with ABh and Pingala's Zhōng-lùn. $\quad 4$ ) Saito 2019, 15.

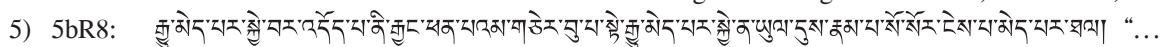
[Those who] assert the arising without cause are the [*loka]āyata or *nirgrantha. [However,] if [things] arose without cause, it would result that there would be no individual certainty about the place, time and aspects.” 6) Kamarid $(2019,235)$. 7) Yoshimizu $(2020,1194)$. 8) See Yoshimizu (2020, 1194ff).

\section{Abbreviations}

ABh Akutobhayā by Nāgārjuna (?). D no. 3829, P no. 5229. BP BuddhapālitaMūlamadhyamakavrtti. D no. 3842, P no. 5242. $\quad$ MMK Mūlamadhyamakakārikā by Nāgārjuna. See Ye 2011. PP Prajñāpradīpa by Bhāviveka. D no. 3853, P no. 5253. PsP Prasannapadā by Candrakīrti. D no. 3860, P no. 5260. See La Vallée Poussin 1903-1913.

\section{References}

La Vallée Poussin, L. de, ed. 1903-1913. Mūlamadhyamakakārikās (Mādhyamikasūtras) de Nāgārjuna avec la Prasannapadā Commentaire de Candrakīrti. Bibliotheca Buddhica 4. St.-Pétersbourg: Commissionnaires de l'Académie impériale des sciences. Repr., Tokyo: Meicho-Fukyu-kai, 1977. Kamarid, D. 2019. "Introductory Remarks on Pa tshab Nyi ma grags's Commentary of the Mūlamadhyamakakārikā." Sengokuyama Journal of Buddhist Studies XI: 258-224. Saito, Akira. 2019. "Bhāviveka versus Candrakīrti on the Logic of Mūlamadhyamakakārikā: Negation of Arising in the Four Possible Ways." International Journal of Buddhist Thought and Culture 29(1): 11-17. Ye, Shaoyong 叶少勇. 2011. Zhunglunsong: Fanzanghan Hejiao, Daodu, Yizhu 中论颂: 梵藏汉合校·导读·译注 (Mūlamadhyamakakārikā: New Editions of the Sanskrit, Tibetan and Chinese Versions, with Commentary and a Modern Chinese Translation). Shanghai: Zhongxi Book Company. Yoshimizu, Chizuko. 2020. "Updating Prāsangika and prasanga." Journal of Indian and Buddhist Studies 68(3): 1193-1199.

Key words prasanga, *Prāsangika, Pa tshab Nyi ma grags, MMK, dBu ma rtsa ba shes rab kyi ți ka sGron ma gsal bar byed pa

(International College for Postgraduate Buddhist Studies, PhD Candidate) 